\title{
Publisher's Note: Phase errors and their effect on undulator radiation properties [Phys. Rev. ST Accel. Beams 16, 010704 (2013)]
}

\author{
Richard P. Walker \\ (Received 19 February 2013; published 25 February 2013)
}

DOI: 10.1103/PhysRevSTAB.16.029901

PACS numbers: 41.60.Ap, 99.10.Fg

This paper was published online on 27 January 2013 with an error in Ref. [19]. Reference [19] should read as "M. Eriksson et al., in Proceedings of the International Particle Accelerator Conference, San Sebastian, Spain, 2011, p. 3026." The reference has been corrected online as of 19 February 2013.

Published by the American Physical Society under the terms of the Creative Commons Attribution 3.0 License. Further distribution of this work must maintain attribution to the author(s) and the published article's title, journal citation, and DOI. 